\title{
Phylogenetic Relationship of Barnacles (Fam:Balanidae) Sampled on Artificial Substrata of Kuala Selangor and Morib
}

\author{
N N Roseman, R Rasol", A Ismail, H R Singh, F Z M Yusof \\ School of Biological Sciences, Faculty of Applied Sciences, Universiti Teknologi MARA, 40450 Shah Alam, Selangor, Malaysia. \\ *Corresponding author E-mail: rafid738@salam.uitm.edu.my
}

\begin{abstract}
Barnacles are marine sessile crustacean inhabiting intertidal areas of the Selangor coastline. They are seen attaching themselves to rocks and artificial structures such as jetty, piers, boats and sea walls. Being the most successful biofoulers, barnacles cause economic losses to some extent. Most of barnacles study focused on morphological identification only. Since molecular method gave more accurate results by sequence comparison, species identification was done on samples of obviously different species inhabiting artificial substrata by using mitochondrial 16S rDNA identification. In Kuala Selangor, there was only one species found on artificial substrata in Bagan Pasir and Pasir Penambang which was identified as Amphibalanus cirratus. Two species that differed in their morphological characteristics found on Morib sea walls were identified as Amphibalanus cirratus and Chthamalus malayensis. Phylogenetic tree based on the 16S rDNA showed that all the samples were in the same cluster reflecting that they are in the same clade.
\end{abstract}

Keywords: Barnacles; biofoulers; $16 S$ rDNA identification; Morib; Kuala Selangor

\section{Introduction}

The Balanidae comprise the family of sessile barnacles of the order Sessilia. The family Balanidae was originally proposed by Leach in the year 1817, containing all known sessile barnacles. Darwin then divided the Balanidae into two subfamilies namely, Balaninae and Chthamalina. In 1916, Pilsbry raised Darwin's Balanidae to the suborder level, Balanomorpha and the Balaninae to Balanidae s.s. which he then subdivided into three subfamilies which are Balaninae, Chelonibiinae and Coronlulinae. Newman and Ross (1976) revised the taxonomy of the Balanomorpha transferred many taxa related to the Balanidae to other taxonomic groups. Currently, the Balanidae contains approximately 94 extant and 114 fossils species (Pitombo, 2004) and are distributed among three subfamilies which are Balaninae, Megabalaninae and Concavinae. Newman (1979) proposed the subfamily Megabalaninae and grouped similar species which have tubiferous radii while the subfamily Concavinae was created by Zullo (1992) which having the scutum radially striate. The remainder of theBalanidae was left under Balaninae and presently still lacks a formal description. Currently, there are a few studies that have been done on the barnacles which are in the family Balanidae in Malaysia (Amir et al., 2013) where these studies emphasized on the morphological characteristic of the family Balanidae. There is yet no molecular taxonomy for the species of barnacles in family Balanidae.

\subsection{Studies utilizing molecular markers in barnacles}

Ribosomal DNA or rDNA is a DNA sequence that codes for ribosomal RNA. Ribosomal DNA sequences have been aligned and compared in several numbers of living organisms. This approach has provided huge amount of information about phylogenetic rela- tionships (Hillis and Dixon, 1991). The rDNA is very useful in phylogenetic analysis because different regions of the rDNA repeat unit evolve at very different rates. Stoekle (2003) said that this type of mtDNA genes are becoming an attractive site as these genes would be shared among the various species as it does not contain introns that makes the amplification process complicated. As for the mitochondrial genes, which are the $12 \mathrm{~S}$ rDNA and the 16S rDNA they can evolve faster compared to the nuclear genes (Hillis and Dixon, 1991). They also are easily amplified by the use of polymerase chain reaction. Mitochondrial gene sequence is greatly used in molecular taxonomy and phylogeny (Patwardhan et al., 2014).

Malay and Michonneau (2014) utilized various types of markers to study phylogenetics and morphological evolution of coraldwelling barnacles. The markers used were Cytochrome C Oxidase, mitochondrial 16S and 12S ribosomal DNA, nuclear $18 \mathrm{~S}$ ribosomal DNA and histone 3. The evolution of the coral-dwelling barnacles was explored in this study by using a multi-gene phylogeny and phenotypic trait mapping. Molecular and morphological study done by Crandall et al. (2008) showed that balanids and archeobalanids are mutually paraphyletic. This study was done to recognize the three Balanoid families which are Balanidae, Archeobalanidae and Pyrgomatidae. The Balanoidea can be classified as a large superfamily of free-living and symbiotic acorn barnacles (Malay and Michonneau, 2014). This particular study focused on the phylogenetic systematics of Pyrgomatidae, which is a morphologically and ecologically distinctive group that was obligately associated with hard corals. The objective of the study done by Malay and Michonneau (2014) was to investigate the evolution of Pyrgomatidae by using both molecular and morphological approaches.

Another study that used the same molecular markers has been done by Simon et al. in 2007. In this study, the markers that being used were two mitochondrial genes (12S rDNA and $16 \mathrm{~S}$ rDNA) and a nuclear gene (18S rDNA). Molecular tools have 
been applied in this study to identify the relationships within the Pyrgomatidae and the position of this taxon in Balanoidea. Eight pyrgomatid genera were identified in the early $19^{\text {th }}$ century and their taxonomy were described. However, they were not complying with the phylogeny of family Pyrgomatidae (Ross and Newman, 1973). The phylogenetic relationships of Pyrgomatidae have been challenging and problematic to establish due to the use of non-cladismatic systematics (Simon et al., 2007). The noncladismatic systematics only pinpoints the ancestor-descendent relationship and not the sister-clade relationship. This study used partial sequences of the markers to derive the molecular phylogeny of the Pyrgomatids. The results from their study suggested the possibility on the paraphyly of the Pyrgomatidae and allowed them to reject the previous study done which classified that particular barnacles based on morphological characteristics.

In addition, in 1999 a study has been conducted to determine the speciation and phenotypic plasticity in coral inhabiting barnacles (Mokady et al., 1999). This study utilized $12 \mathrm{~S}$ rDNA as the marker. The authors stated that the speciation and the phenotypic plasticity were two most utmost strategic modes which enable a given taxon to populate a broad ecological niche. Phenotypic plasticity can be defined as changes in an organism's behaviour, morphology and physiology which is due to its adaptation to their unique environment (Price et al., 2003). Few studies have been done towards barnacles with no attempt in observing the differences between the barnacles ecologically (Soong and Chang, 1983). The results of the author's study suggested that closely related barnacle used opposite strategies in populating a suite of live-coral substrates. Two pyrgomatine barnacles were chosen as a model to contrast between speciation and phenotypic plasticity. From the results obtained, it showed that Savignium demonstrated large between and within species variation while Cantellius exhibits a low genetic variability, despite inhabiting a wide range of corals.

Apart from that, James et al. (2000) has done a study on the phylogeny of the Thoracican barnacles based on the 18S rDNA sequences. The selected Thoracican barnacles were studied based on the $18 \mathrm{~S}$ rDNA sequences to determine their phylogenetic relationship. The analyses made by them were found to be similar with the previous study done morphologically but differed with the earlier analysed based on $18 \mathrm{~S}$ rDNA sequences. By using that particular sequence, also their study managed to obtain a greater resolution which often considered as slowly evolving being useful in higher taxonomic level. With that, it allows a considerable resolution of relationship of barnacles within the Thoracica.

\subsection{Economic value of barnacles}

Due to the unique adaptation to the sessile mode of life, barnacles become the most successful form of fouling or biofouling animals. Biofouling can be defined as the accumulation of organism on submerged or man-made surfaces (Holm, 2012). The organisms that usually attach themselves to man-made structure are microalgae, hydrozoan, tubeworm and barnacles are organisms that cause biofouling. Christie and Dalley (1987) said that barnacles are the most successful animal as biofoulers. Some of the barnacles which caused this biofouling effects are the Balanus $s p$. The ability of a particular species to cause fouling effect largely depends on the similarity on their natural habitat and the artificial habitat provided by man. The most prominent effect of fouling which is cause by barnacles is that, the fouling increases the frictional resistance of the ships to move through water. Due to this effect, it resulted in an increase in power and fuel consumption which is required for the ship to speed up (Holm, 2012). Other than that, barnacles are also the cause in the fouling of oil platforms and in pipework which carrying seawater (Christie and Dalley, 1987). On top of all the issue, one additional issue that mostly concern is on their implication in the corrosion activity (Southward, 1987). The environment created beneath the settlement of the barnacle might create a suitable and favorable condition for growth of bacteria and this will cause an accelerated corrosion to the surface of settlement. Nevertheless, on a coated surface or structure barnacles could be seen to be even directly as the cause of corrosion. This is due to their larva where they search for cracks between the surface and settle inside that. This can cause a serious effect to the surface itself due to the growth of their shell plates.

\section{Materials and Methods}

\subsection{Sampling materials}

The adult barnacles were hand collected from artificial substrata along the intertidal coastal areas of Selangor from jetty piles at Bagan Pasir ( $3^{\circ} 56^{\prime} 00^{\prime \prime} \mathrm{N}$ and $\left.100^{\circ} 49^{\prime} 00^{\prime \prime} \mathrm{E}\right)$ and Pasir Penambang $\left(3.3499^{\circ} \mathrm{N}\right.$ and $\left.101.2530^{\circ} \mathrm{E}\right)$ and from the Morib sea walls $\left(2.7495^{\circ} \mathrm{N}\right.$ and $\left.101.4426^{\circ} \mathrm{N}\right)$. The samples were collected from three piers selected randomly in Bagan Pasir, three piers in Pasir Penambang and two quadrats $(5 \mathrm{~cm} \times 5 \mathrm{~cm})$ in Morib sea walls. Sampling was carried out during low tide where the barnacles could be accessed. At Bagan Pasir and Pasir Penambang, only one morphological type was identified. Three samples were taken at 5 metres above water line (upper region) and three samples taken 2 metres above water line (lower region). Two morphologically different types were noted from the Morib sea wall where samples were taken from upper region (4 metres above the sand during low tide) and the lower region ( 2 metres above the sand during low tide). The barnacles were washed with clean water and immediately immersed in $95 \%$ ethanol to conserve the DNA for the extraction process.

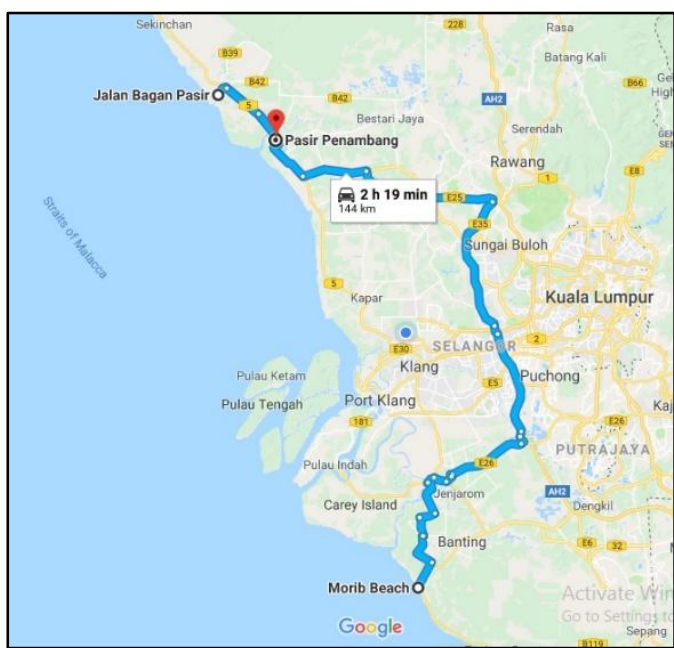

Fig. 1: Location of barnacle sampling site (Bagan Pasir, Pasir Penambang and Morib Sea Wall)

\subsection{DNA manipulation and PCR}

Total genomic DNA was extracted from the preserved barnacle tissues using EasyPure ${ }^{\circledR}$ Marine Animal Genomic DNA Kit (Transgene Biotech) according to the manufacturer's instructions. The sequences and primers used to amplify the DNA sequence in the polymerase chain reaction (PCR) were obtained from the previous study (Malay and Michonneau, 2014). The PCR process was carried out by using $16 \mathrm{~S}$ forward primer 5' GACCGTGCTAAGGTAGCATAATC-3' and 16S reverse primer 5'-CCGGTCTGAACTCAAATCGTG-3' (Malay and Michonneau, 2014). PCR reaction was conducted using FIREPol ${ }^{\circledR}$ DNA Polymerase kit by Solis BioDyne in a mixture of $2.5 \mu \mathrm{l}$ of PCR Buffer B (10x), $2.5 \mu 1 \mathrm{MgCl}_{2}$ (25mM), 0.25 $\mu \mathrm{l}$ dNTPs (20mM), $1 \mu \mathrm{l}$ of forward and reverse primer $(20 \mathrm{mM})$ and $2 \mu \mathrm{l}$ of genomic DNA (50ng/ $\mu \mathrm{l}$ ) and $\mathrm{ddH}_{2} \mathrm{O}$ adjusted to $25 \mu \mathrm{l}$. The PCR was carried out 
by using the cycle at $94^{\circ} \mathrm{C}$ for 5 minutes as the initial denaturation, 35 cycles of denaturation step at $94^{\circ} \mathrm{C}$ for 30 seconds, annealing step of $52.6{ }^{\circ} \mathrm{C}$ for 30 seconds and elongation step at $72{ }^{\circ} \mathrm{C}$ for 30 seconds and final elongation at $72{ }^{\circ} \mathrm{C}$ for 7 minutes. The PCR products were then purified by using QIAquick PCR Purification Kit (Qiagen) and sent for sequencing at First Base Laboratories Sdn Bhd. The data was analysed via MEGA7 software for phylogenetic tree construction.

The phylogenetic tree was deduced by using neighbour-joining method from evolutionary distance data. The operation-al taxonomic units were paired in neighbor-joining method to minimize the total of branch length (Saitou and Nei, 1987). The percentage of replicate trees in which the associated taxa clustered together in the bootstrap test is shown next to the branches in the phylogenetic tree (Felsenstein, 1985). Bootstrap can be defined as a resampling analysis that in-volves taking characters out of the analysis and rebuilding a tree. This bootstrapping analysis is done through many such as 100 or 1000 . The bootstrapping analysis was done for 100 times to produce the phylogenetic tree above. The tree is drawn to scale, with branch lengths in the same units as those of the evolutionary distances used to infer the phylogenetic tree. The evolutionary distances were computed using the Tamura 3-parameter method (Tamura et al., 2004) and in the units of the number of base substitutions per site. The analysis involved 14 nucleotide sequences. All positions containing gaps and missing data were eliminated. There were a total of 344 positions in the final dataset. Megabalanus tintinnabulum was the other species from the same family that would act as the outgroup.

\section{Results and discussion}

All the samples was identified and their phylogenetic relationship was determined. Two species of barnacles Amphibalanaus cirratus and Chthamalus malayensis were identified from the nine samples collected (Figure 2).

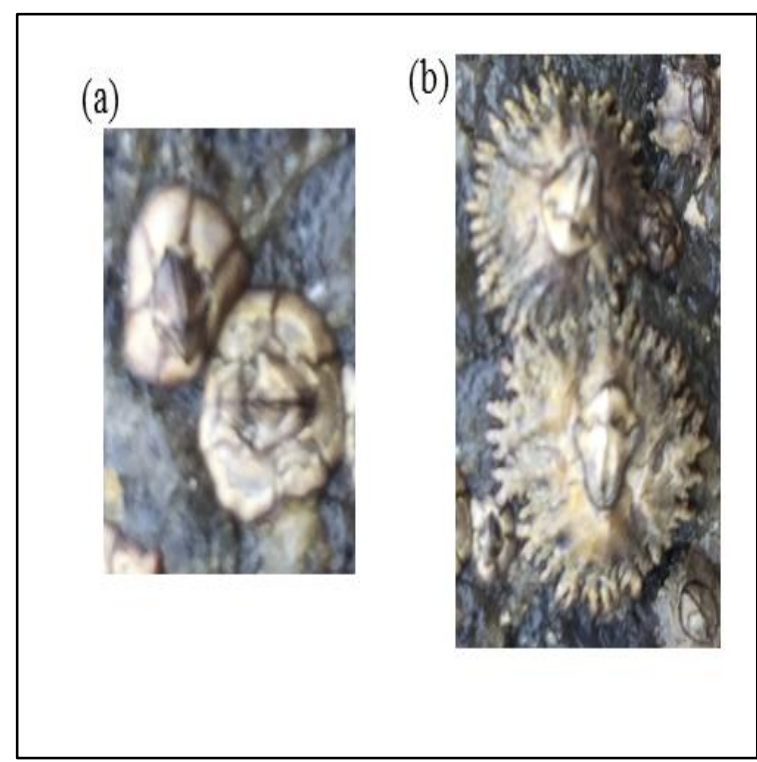

Fig. 2: (a) Amphibalanus cirratus (Bagan Pasir and Pasir Penambang) (b) Chthamalus malayensis (Morib Sea Walls)

The phylogenetic tree shown has the optimal tree with the sum of branch length of 0.2827 . Phylogenetic tree (Figure 3) shows that the samples were clustered into the same clade. Samples from Pasir Penambang and Bagan Pasir were identified as Amphibalanus cirratus and were also $87 \%$ related to Amphibalanus amphitrite. The higher percentage of the samples with A. amphitrite indicate that both the sample and A.amphitrite shows some similarities in their base sequence. The samples from Morib were identified as Chthamalus malayensis.

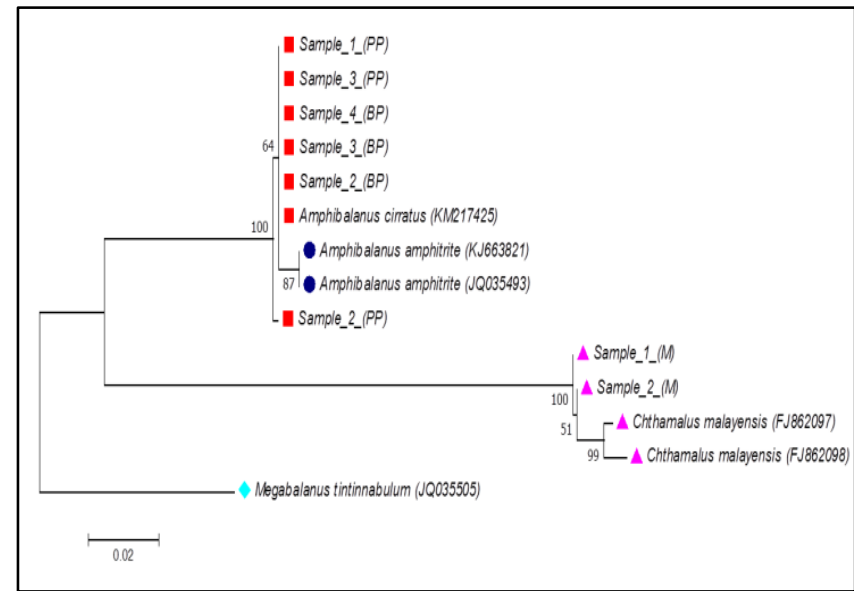

Fig. 3: Phylogenetic tree of samples from Bagan Pasir, Pasir Penambang and Morib

The identification of Amphibalanus sp. is in agreement with the work of Ardura et al., (2016) which stated that this species is distributed from Japan to Malaysia. There are different ways for a species to be introduced into a habitat. Shipping is said to be the most significant way in transferring species across marine regions (Leppakoski et al., 2002). The pathway would be a potential vectors-transport of organism in ballast water and ballast tank sediments. Ballast water is said to be the most important vectors to transfer 7000 species daily across the world ocean (Gollasch and David, 2011). From the sequencing results, only one species of barnacles was acquired from both Bagan Pasir and Pasir Penambang. The identification of the same species of barnacles could be due to the short distance between the two places. Ardura et al. (2016) said that continuous spread of the species with no gaps in distribution of greater than $100 \mathrm{~km}$. Hence, this statement showed that the barnacles in genus Amphibalanus sp. might be distributed all over Kuala Selangor coastal areas and possibly Morib which is $144 \mathrm{~km}$ apart in road distance.

Ardura et al. (2016) also said that fouling behaviour also can increase the gene flow among distant population. Amphibalanus sp. is distributed in warm water and it is likely to be distributed or disperse through human activities through ballast water for larvae and through the vessels fouling for adults in a long distance routes (Chen et al., 2014).

Tsang et al. (2012) states that Chthamalus malayensis distribution lies within the Indo-Malayan region which spans from the Arabian Sea and Bay of Bengal in the Indian Ocean to the Malay Peninsula in the equatorial region. This intertidal species however, was not found in Kuala Selangor (Bagan Pasir and Pasir Penambang). This may have been due to competition with mussels that were found abundant at both areas which may have restricted their establishment. Chthamalus is a common genus of barnacles that is usually found worldwide inhabiting higher parts of the intertidal shores (Newman and Ross, 1976). This genus is often used as a model organism due to their high phenotypic plasticity.

\section{Conclusion}

Based on 16S rDNA identification, the barnacles that were identified along the Selangor coast were Amphibalanus cirratus and Cthamalus malayensis which belonged to the same clade. 16S rDNA can be considered as a reliable method in barnacle identification.

\section{Acknowledgement}

The authors gratefully acknowledge Universiti Teknologi MARA in providing the LESTARI research grant [Project Number: 600IRMI/MYRA 5/3/LESTARI (0119/2016)]. The authors were also greatly indebted to Madam Norfatimah Mohamed Yunos for her tireless guidance 
and knowledge imparted and Miss Diyana Sakinah for her help in sampling.

\section{References}

[1] Amir, N. H., Talib, A., Ahmad, O., \& Yahya, K. (2013, November). The distribution and zonation of barnacles around intertidal shores of Penang Island. In Proceedings of The Annual International Conference, Syiah Kuala University-Life Sciences \& Engineering Chapter (Vol. 3, No. 1)

[2] Ardura, A., Planes, S., and Garcia-Vazquez, E. (2016). Phylogenetic analysis for detection of multiple fouling events: a pilot study of barnacles at Moorea Island (French Polynesia). Crustaceana, 89(8), 863-875.

[3] Chen, H. N., L. M. Tsang, V. C. Chong and B. B. K. Chan. (2014) Worldwide genetic differentiation in the common fouling barnacle. Amphibalanus amphitrite. Biofouling, 30:1067-1078.

[4] Christie, A. O., \& Dalley, R. (1987). Barnacle fouling and its prevention. Barnacle biology, 419-433.

[5] Crandall, K. A., Harp, M., Høeg, J. T., Achituv, Y., Jones, D., Watanabe, H., \& Pérez-Losada, M. (2008). The tempo and mode of barnacle evolution. Molecular phylogenetics and evolution, 46(1), 328-346.

[6] Felsenstein J. (1985). Confidence limits on phylogenies: An approach using the bootstrap. Evolution 39:783-791.

[7] Gollasch, S. and M. David, (2011). Sampling methodologies and approaches for ballast water management compliance monitoring. Traff. Environ., 33: 397-405.

[8] Hillis, D. M., \& Dixon, M. T. (1991). Ribosomal DNA: molecular evolution and phylogenetic inference. Quarterly Review of Biology, 411-453.

[9] Holm, E. R. (2012). Barnacles and biofouling. Integrative and comparative biology, 52(3), 348-355.

[10] James H., D., Maxson, L. S., Braithwaite, L. F., \& Crandall, K. A. (2000). Phylogeny of the thoracican barnacles based on 18S rDNA sequences. Journal of Crustacean Biology, 20(2), 393-398.

[11] Leppakoski, E., S. Gollasch and S. Olenin (eds.), (2002). Invasive aquatic species of Europedistribution,impact and management. (Kluwer, Dordrecht).

[12] Malay, M. C. M. D., \& Michonneau, F. (2014). Phylogenetics and morphological evolution of coral-dwelling barnacles (Balanomorpha: Pyrgomatidae). Biological Journal of the Linnean Society, 113(1), 162-179.

[13] Mokady, O., Loya, Y., Achituv, Y., Geffen, E., Graur, D., Rozenblatt, S., \& Brickner, I. (1999). Speciation versus phenotypic plasticity in coral inhabiting barnacles: Darwin's observations in an ecological context. Journal of Molecular Evolution, 49(3), 367-375.

[14] Newman, W. A. \& Ross, A. (1976). Revision of the Balanomorph barnacles including a catalogue of the species. San Diego Society of Natural History Memoirs, 9, 1-108.

[15] Newman, W. A. (1979). On the biogeography of Balanomorph barnacles of the southern ocean including new balanid taxa. Proceedings of the International Symposium on Marine Biogeography and Evolution in the Southern Hemisphere, Auckland, New Zealand, July 1978. New Zealand DSIR Information Series, 137 (1), 279-306

[16] Patwardhan, A., Ray, S., \& Roy, A. (2014). Molecular markers in phylogenetic studies-A review. Journal of Phylogenetics \& Evolutionary Biology, 2014.

[17] Pitombo, F. B. (2004). Phylogenetic analysis of the balanidae (Cirripedia, Balanomorpha). Zoologica Scripta, 33(3), 261-276.

[18] Price, T. D., Qvarnström, A., \& Irwin, D. E. (2003). The role of phenotypic plasticity in driving genetic evolution. Proceedings of the Royal Society of London B: Biological Sciences, 270(1523), 1433-1440.

[19] Saitou N. and Nei M. (1987). The neighbor-joining method: A new method for reconstructing phylogenetic trees. Molecular Biology and Evolution 4:406-425.

[20] Simon-Blecher, N., Huchon, D., \& Achituv, Y. (2007). Phylogeny of coral-inhabiting barnacles (Cirripedia; Thoracica; Pyrgomatidae) based on $12 \mathrm{~S}, 16 \mathrm{~S}$ and $18 \mathrm{~S}$ rDNA analysis. Molecular Phylogenetics and Evolution, 44(3), 1333-1341.

[21] Soong KY, Chang KH (1983) The coral-inhabiting barnacles (Crustacea:Thoracica: Pyrgomatidae) from southern most coast of Taiwan.Bull Inst Zool Acad Sinica 22:243-254

[22] Southward, A. J. (1987) Barnacle biology. Balkema, Rotterdam.

[23] Stoeckle, M. 2003. Taxonomy, DNA, and the bar code of life. BioScience 53(9): 796-797.
[24] Tamura K., Nei M., and Kumar S. (2004). Prospects for inferring very large phylogenies by using the neighbor-joining method. Proceedings of the National Academy of Sciences (USA) 101:11030-11035.

[25] Tamura K., Stecher G., Peterson D., Filipski A., and Kumar S. (2013). MEGA6: Molecular Evolutionary Genetics Analysis version 6.0. Molecular Biology and Evolution30: 2725-2729.

[26] Tsang, L.M., Wu, T.H., Shih, H., Chu, K.H.W., and Chan, K.K.,B. (2012) Genetic and Morphological Differentiation of the IndoWest Pacific Intertidal Barnacle Cthalamus malayensis. Integrative and Comparative Biology, 52(3), 388-409.

[27] Zullo, V. A. (1992). Revision of the balanid barnacle genus Concavus Newman, 1982, with a description of a new subfamily, two new genera, and eight new species. Journal of Palaeontology, 66 (6), 1-46. 